\title{
Effects of light availability on leaf attributes and seedling growth of four tree species in tropical dry forest
}

Sachchidanand Tripathi ${ }^{1,2^{*}}$, Rahul Bhadouria ${ }^{1,3}$, Pratap Srivastava ${ }^{4}$, Rajkumari S. Devi ${ }^{2}$, Ravikant Chaturvedi ${ }^{5}$ and A. S. Raghubanshi ${ }^{6}$

\begin{abstract}
Background: In tropical dry forests, variation in understory light availability due to season and canopy tree density could be a governing factor in establishment and growth of tree seedlings. Species with varying life history traits are expected to respond differentially to such heterogeneity. We investigated the response of seedlings of four tree species in a tropical day forest in relation to spatiotemporal variability of light. We attempt to explore the role of leaf attributes in explaining intra- and inter-specific variations in relative growth rate. Four study sites, each with three contrasting canopy conditions, were selected along a soil moisture gradient. Seedlings of four tree species (viz., Acacia catechu, Bridelia retusa, Lagerstroemia parviflora, and Shorea robusta), varying in life history traits, were monitored for seasonal variations in growth traits across canopy condition and sites for 2 years.
\end{abstract}

Results: We observed a larger variation in leaf attributes for pioneer species. A. catechu showed highest mean values for leaf dry matter content, leaf nitrogen concentration, leaf phosphorus concentration, net stomatal conductance, net photosynthetic rate, and relative growth rate in high light conditions. S. robusta and B. retusa demonstrated highest mean values for all the leaf attributes (except leaf dry matter content) in low light conditions. However, intermediate values for leaf attributes were observed in L. parviflora which preferred moderate light conditions.

Conclusions: Seasonal variations in light availability at the forest floor appear to play an important role in the establishment and growth of tree seedlings in seasonal dry forests. Leaf attributes can be used to explain intra- and inter-specific variation in response to light availability. Leaf attributes in combinations can be used to predict relative growth rate of tree species in tropical dry environment, which apart from soil moisture is also determined by light availability due to seasonal changes and canopy tree density.

Keywords: Tropical dry forest, Tree seedlings, Light intensity, Leaf attributes, Pioneer species, Shade tolerance

\section{Introduction}

Amount of light available on the forest floor has been reported as a strategic environmental regulator which governs intrinsic growth behavior of residing plant species (Augspurger 1984; Walters and Reich 1996; Bhadouria et al. 2018). Heterogeneity in the availability of light in a forest is associated with morphological and

\footnotetext{
* Correspondence: snt191@gmail.com

${ }^{1}$ Ecosystems Analysis Laboratory, Department of Botany, Institute of Science, Banaras Hindu University, Varanasi 221005, India

${ }^{2}$ Department of Botany, Deen Dayal Upadhyaya College, University of Delhi, New Delhi 110078, India

Full list of author information is available at the end of the article
}

physiological adaptations, and therefore directly determines the species composition at community level (Lüttge et al. 2002; Bhadouria et al. 2016, 2017a). Valladares and Niinemets (2008) suggested that the understanding of species-specific response to acclimatize and grow in low-light environments will help in the assessment of ecosystem responses to global climate change. Mulkey and Wright (1996) concluded that variability in light distribution is a determining factor in seasonal tropical forests, as spatial and temporal dynamics of light and moisture availability inflict major constraints on leaf 
phenology and canopy occupancy of the plants between dry and wet seasons.

Growth period of tropical dry forest (TDF) tree seedlings is restricted to the rainy season mainly due to adequate soil moisture availability, which provides optimal conditions for seedling growth. As dry deciduous forest in India is renewed by leaf flushing in the dry and hot pre-rainy seasons (Singh and Singh 1992), the lush green foliage during the subsequent rainy season reduces the light intensity reaching to seedlings growing understory and therefore may produce a limiting light condition for their growth. On the contrary, seedlings growing in open canopies or at forest edges experience high light intensity. It demonstrates the heterogeneity in environmental conditions during the most favorable period for the growth. However, during the dry season, soil water availability declines rapidly, inflicting the growth and survival constraint on tree seedlings (Gerhardt 1996). In these conditions, the shady environment provides a habitat of vital significance providing higher soil moisture availability and having reduced transpiration load (Lieberman and $\mathrm{Li}$ 1992; Huante and Rincón 1998; Gerhardt 1996). In addition, the sporadicity of wet and dry periods in annual cycle imposes further miscellany within the same habitat. Seedlings of different species are, therefore, expected to respond differently to these heterogeneous conditions, as they vary in their growth behavior, drought, and shade tolerance (Gerhardt and Hytteborn 1992; Marod et al. 2004; Khurana and Singh 2001a; Bhadouria et al. 2020).

Plant's genotype responds to the variability of environmental conditions (e.g., light, soil moisture, and soil nutrient availability) by producing different phenotypes (Huante et al. 1995; Markesteijn et al. 2007; Lusk et al. 2008). A community of species with varying phenotypic plasticity is augmenting to ecosystem function and stability (Coomes et al. 2009; Kröber et al. 2012). Moreover, an estimation of the degree of plasticity of different plant species is critical for the interpretation of the functional role of species in that community (Böhnke and Bruelheide 2013). In tropical dry forests, soil moisture availability is critical for the survival and growth of plants, where they show higher plasticity in response to the variations in soil moisture availability as compared to the variability in light conditions (Khurana and Singh 2001a; Markesteijn et al. 2007; Singh et al. 2017). It is, therefore, necessary to estimate the light-related plasticity in leaf attributes of tree seedlings of seasonal tropical dry forests (TDFs) to generate a better understanding of species-specific response and inter-specific differences in an ecosystem of higher spatial and temporal heterogeneity.
Deciduousness is claimed to be a drought avoiding strategy in TDF tree species (Poorter and Markesteijn 2008). In general, deciduous and shade-intolerant species tend to possess more plasticity in growth traits as compared to shade-tolerant and evergreen species (Rozendaal et al. 2006; Portsmuth and Poorter 2007; Poorter et al. 2009). Leaves respond to varying light environments by exhibiting considerable adjustments in morphological, anatomical, and physiological traits (Craven et al. 2011). These adjustments are reported to be more pronounced in deciduous species as compared to the evergreens (Walters and Reich 1999; Lusk et al. 2008). Lusk et al. (2008) reported that plasticity was similar for both deciduous and evergreen species along light gradients; however, they differ in evolutionary response. The leaf attributes associated with the worldwide leaf economic spectrum can be used as proxy to understand the species-specific as well as inter-specific responses to different environments (Wright et al. 2004). Leaf attributes are inter-related in their function and appear to be associated positively or negatively, ultimately influencing relative growth rate (RGR) of the plants (Chaturvedi et al. 2011, 2012). For example, specific leaf area (SLA), which relates to the light interception, determines the net photosynthetic rate $\left(A_{\text {net }}\right)$ and RGR (Reich et al. 1997; Poorter and Garnier 2007). Leaf dry matter content (LDMC) which indicates leaf tissue density and nutrient retention capacity is positively associated with the average leaf life span and negatively scaled with RGR of the plant (Cornelissen et al. 2003; Poorter and Garnier 2007). Leaf chlorophyll content $(\mathrm{Chl})$ indicates the physiological acclimation of plant along an environmental gradient (Popma and Bongers 1988; Lichtenthaler 1998). Leaf nitrogen concentration (LNC) and leaf phosphorus concentration (LPC) influence net stomatal conductance ( $\left.\mathrm{Gs}_{\text {net }}\right), A_{\text {net }}$ SLA, and RGR (Reich et al. 1991; Cornelissen et al. 2003). Moreover, LNC is associated with the varying physiological activity of plants in different environments (Hikosaka 2004, 2010; Kattge et al. 2009).

Many studies have reported modulations in leaf attributes in response to the light gradients which brings change in RGR (Huante and Rincón 1998; Huante and Rincón 1998; Landhäusser and Lieffers 2001; Markesteijn et al. 2007 and references therein; Tripathi and Raghubanshi 2014). For instance, pioneer and light demanding species growing in light tend to possess higher LDMC, LNC, LPC, $A_{\text {net }}$, Gs net $_{\text {, }}$ and lower SLA and Chl as compared to the individuals of same species growing in shade conditions. On the other hand, non-pioneer and shade-tolerant species display lesser adjustments in functional traits relative to the pioneer and light demander species (Markesteijn et al. 2007 and references therein).

Considering the abovementioned heterogeneity for growth of tree seedlings in TDF environment, a sound understanding of the behavior of leaf attributes 
underlying plant adaptations is critical for the prediction and explanation of species-specific and inter-specific responses in relation to environmental variability in light conditions. Comprehensive studies relating leaf attributes to growth in tree seedlings under natural conditions are scarce for TDF. We hypothesize that seasonality will affect physiological traits along with RGR (hypothesis-1). As light-demanding and pioneer species are more responsive to higher light availability as compared to shade tolerant (Rincon and Huante 1993), we hypothesize that RGR of light-demanding and pioneer species will be higher as compared to shade tolerants under high light conditions (hypothesis-2). Leaf attributes vary systematically with a species' juvenile light requirement (Valladares and Niinemets 2008); therefore, we hypothesize that leaf attributes affect the growth of tree seedlings, both alone and in combination under different light conditions.

\section{Material and methods}

\section{Study site}

The present study was carried out in a TDF at four adjoining sites, Hathinala, Gaighat, Harnakachar, and
Ranitali situated in the Vindhyan Highlands (24 $24^{\prime} 13^{\prime}$ ' $\mathrm{N}, 83^{\circ} 04^{\prime} 05^{\prime \prime}$ E) of Sonebhadra district in Uttar Pradesh, India (Fig. 1). The sites were selected to represent a range of light availability at the forest floor. The description of four sites including location, physicochemical properties of soil, average light availability, and dominant tree species are given in Table 1. Soils of study sites are residual, ultisols, and sandy loam in texture. The most important rock of the area is red-colored, fine-textured sandstone generally underlain by shale and limestone. Meteriological data were collected from Obra and Renukoot meteriological station as Ranitali is nearest to Obra and Hatinala is nearest to Renukoot. Mean annual rainfall during 1980-2010 ranged between 1196 (Renukoot) and $952 \mathrm{~mm}$ (Obra) (Chaturvedi et al. 2012). The natural vegetation of the study sites comprises species such as Acacia catechu (L.f.) Willd., Anogeissus latifolia (Roxb. ex DC.) Wallich ex Beddome, Boswellia serrata Triana \& Planch., Briedelia retusa (Linn.) Spreng., Buchanania lanzan Spreng., Diospyros melanoxylon Bakh., Hardwickia binata Roxb., Lagerstroemia parviflora Roxb., Lannea coromandalica (Houtt.) Merril, Shorea robusta Roth., and Terminalia tomentosa Roxb.

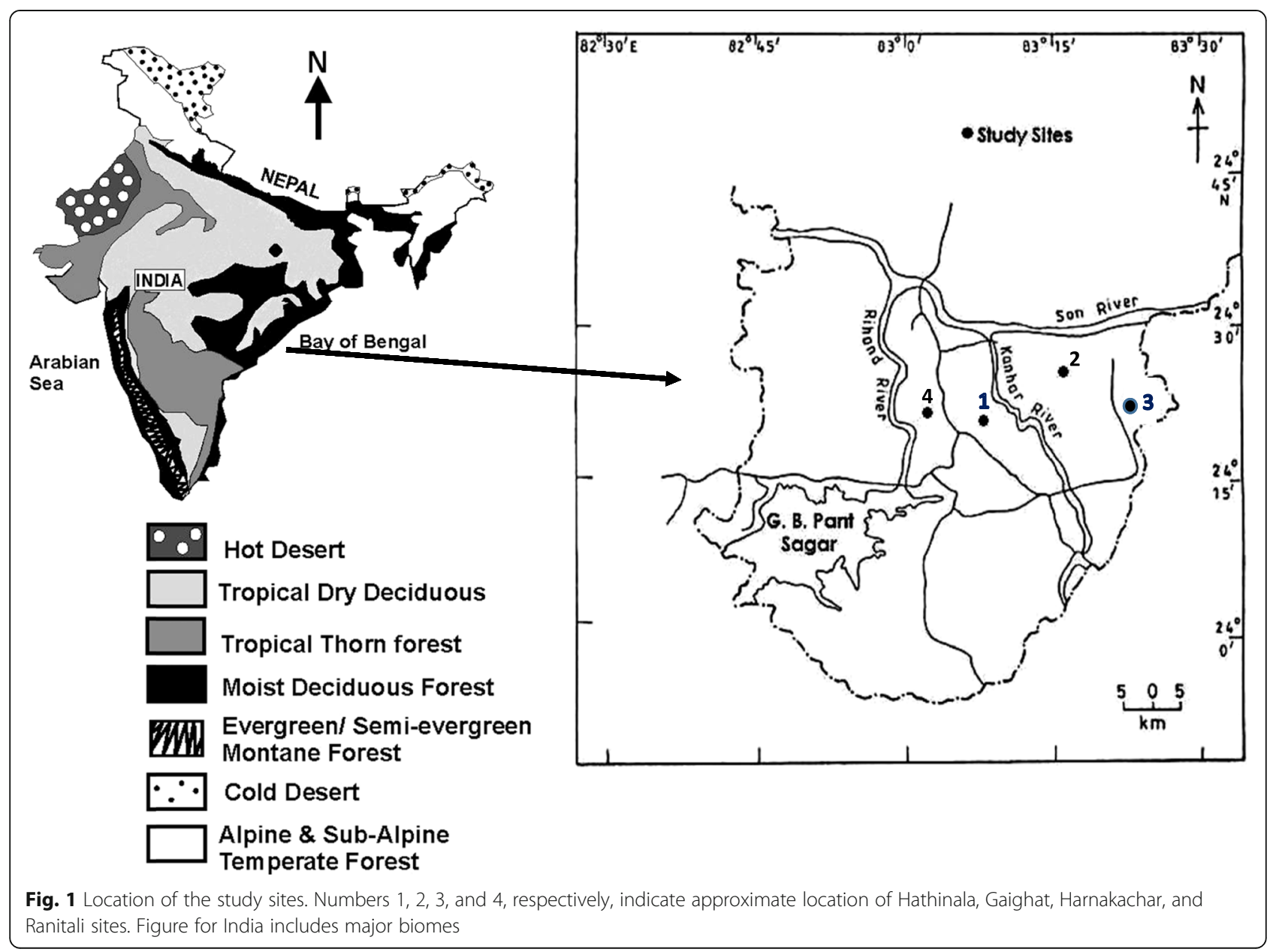


Table 1 Location, light, and physicochemical properties of soil and major tree species of four study sites

\begin{tabular}{|c|c|c|c|c|}
\hline Parameter & Hathinala & Gaighat & Harnakachar & Ranitali \\
\hline Location & $\begin{array}{l}24^{\circ} 18^{\prime} 07^{\prime \prime} \mathrm{N} \text { and } \\
83^{\circ} 05^{\prime} 57^{\prime \prime} \mathrm{E}\end{array}$ & $\begin{array}{l}24^{\circ} 24^{\prime} 13^{\prime \prime} \mathrm{N} \text { and } \\
83^{\circ} 12^{\prime} 01^{\prime \prime} \mathrm{E}\end{array}$ & $\begin{array}{l}24^{\circ} 18^{\prime} 33^{\prime \prime} \mathrm{N} \text { and } \\
83^{\circ} 23^{\prime} 05^{\prime \prime} \mathrm{E}\end{array}$ & $\begin{array}{l}24^{\circ} 18^{\prime} 11^{\prime \prime} \mathrm{N} \text { and } \\
83^{\circ} 04^{\prime} 22^{\prime \prime} \mathrm{E}\end{array}$ \\
\hline Altitude (m.a.s.l.) & 291 & 245 & 323 & 287 \\
\hline Light & $780.07^{\mathrm{a}}( \pm 92.0)$ & $1049.0^{\mathrm{a}, \mathrm{b}}( \pm 60.7)$ & $1080.0^{b}( \pm 62.06)$ & $1197.0^{\mathrm{b}}( \pm 75.3)$ \\
\hline Soil moisture content (SMC, \%) & $14.40^{\mathrm{a}}( \pm 0.73)$ & $12.06^{\mathrm{a}, \mathrm{b}}( \pm 0.53)$ & $11.0^{\mathrm{b}}( \pm 0.63)$ & $8.0^{\complement}( \pm 0.74)$ \\
\hline Bulk density $\left(\mathrm{g} \mathrm{cm}^{-3}\right)$ & $1.31^{\mathrm{a}}( \pm 0.04)$ & $1.35^{\mathrm{a}}( \pm 0.02)$ & $1.27^{\mathrm{a}}( \pm 0.03)$ & $1.26^{\mathrm{a}}( \pm 0.02)$ \\
\hline Clay (\%) & $10.97^{\mathrm{a}}( \pm 0.56)$ & $7.14^{\mathrm{b}}( \pm 0.51)$ & $4.83^{\mathrm{C}}( \pm 0.32)$ & $3.03^{d}( \pm 0.31)$ \\
\hline Silt (\%) & $30.97^{\mathrm{a}}( \pm 0.28)$ & $31.86^{\mathrm{a}}( \pm 0.60)$ & $26.17^{b}( \pm 0.37)$ & $26.42^{b}( \pm 0.37)$ \\
\hline Sand (\%) & $58.05^{\mathrm{a}}( \pm 0.32)$ & $61.0^{\mathrm{b}}( \pm 0.70)$ & $69.0^{c}( \pm 0.63)$ & $70.5^{\mathrm{c}}( \pm 0.65)$ \\
\hline Soil pH & $6.85^{\mathrm{a}}( \pm 0.05)$ & $6.44^{\mathrm{b}}( \pm 0.04)$ & $6.54^{b}( \pm 0.05)$ & $6.40^{\mathrm{b}}( \pm 0.04)$ \\
\hline Organic C (\%) & $1.92^{\mathrm{a}}( \pm 0.08)$ & $1.81^{\mathrm{a}}( \pm 0.05)$ & $1.46^{\mathrm{b}}( \pm 0.04)$ & $1.28^{\mathrm{b}}( \pm 0.01)$ \\
\hline Total N (\%) & $0.17^{\mathrm{a}}( \pm 0.04)$ & $0.15^{\mathrm{a}}( \pm 0.03)$ & $0.13^{\mathrm{b}}( \pm 0.01)$ & $0.12^{\mathrm{b}}( \pm 0.02)$ \\
\hline Total P (\%) & $0.05^{\mathrm{a}}( \pm 0.02)$ & $0.03^{\mathrm{b}}( \pm 0.01)$ & $0.02^{b}( \pm 0.00)$ & $0.02^{\mathrm{b}}( \pm 0.01)$ \\
\hline Species richness ( no. of species $\left.0.1 \mathrm{ha}^{-1}\right)^{*}$ & $17^{\mathrm{a}}( \pm 2)$ & $14^{\mathrm{b}}( \pm 1)$ & $16^{\mathrm{a}, \mathrm{b}}( \pm 1)$ & $16^{\mathrm{a}, \mathrm{b}}( \pm 1)$ \\
\hline Density of juveniles (stems ha $\left.{ }^{-1}\right)^{* *}$ & $13822^{\mathrm{a}}( \pm 371)$ & $8733^{\mathrm{b}}( \pm 378)$ & $9850^{\mathrm{b}}( \pm 361)$ & $7044^{c}( \pm 645)$ \\
\hline Major tree species & $\begin{array}{l}\text { Shro, Teto, Lapa, } \\
\text { and Bula }\end{array}$ & $\begin{array}{l}\text { Shro, Bula, Teto, } \\
\text { and Dime }\end{array}$ & $\begin{array}{l}\text { Shro, Sofe, Teto, } \\
\text { and Bula }\end{array}$ & $\begin{array}{l}\text { Acca, Lapa, Anla, } \\
\text { and Teto }\end{array}$ \\
\hline
\end{tabular}

$\overline{a, b, c, d}$ Values affixed with different letters in a row are significantly different from each other at $P<0.05 .{ }^{*}, * *$ Chaturvedi et al. (2012). Values in parentheses show the standard error. Abbreviations: Acca = Acacia catechu, Anla = Anogeissus latifolia, Bula = Buchanania lanzan, Dime $=$ Diospyros melanoxylon, Lapa = Lagerstroemia parviflora, Shro $=$ Shorea robusta, Sofe $=$ Soymida febrifuga, Teto $=$ Terminalia tomentosa

\section{Climate}

The climate of the study area is monsoonal, and about $85 \%$ of the annual rainfall occurs during monsoon season from south-west monsoon, and remaining by the intermittent rainfall in months of December-January and May-June. Mean maximum monthly temperature varies from $20{ }^{\circ} \mathrm{C}$ in January to $46{ }^{\circ} \mathrm{C}$ in June, and mean minimum monthly temperature ranges from $12{ }^{\circ} \mathrm{C}$ in January to $31{ }^{\circ} \mathrm{C}$ in May. For the present study, the year has been divided into four seasons: pre-rainy (AprilJune), rainy (July-September), early post-rainy (October-December), and late post-rainy (January-March). Late post-rainy period is associated with the initiation of leaf fall, and the hot pre-monsoon period relates to the leaf flushing for majority of the species.

\section{Study design}

At each site, three stands differing in light conditions (viz., open canopy, medium canopy, and closed canopy) were identified by measuring light intensities below the tree canopy with the help of Digital Lux Meter (Model LX-101, Taiwan). At each stand, three plots of $1000 \mathrm{~m}^{2}$ area $(50 \times 20 \mathrm{~m})$ were randomly selected. Direct light (photosynthetically active radiation, PAR) measurements were taken at nine random locations in each plot with the help of an LC Pro Console Photosynthesis meter (Model EN 11 ODB, ADC Bioscientific Ltd., England) with PAR sensors as an accessory in the month of September, 2005. For better estimates, light measurements were taken continuously for 3 days at each site, on different dates at 2-h intervals from 08:00 to 16:00. Engelbrecht and Herz (2001) also observed in their study that PAR measurements during a day or a week provides good estimates of relative long-term light conditions in a forest understorey that are useful for comparison among forests. PAR values in each plot across sites significantly differed among all light levels. PAR values at Hathinala ranged from 912 to $1053 \mu \mathrm{mol} \mathrm{m} \mathrm{m}^{-2} \mathrm{~s}^{-1}$ for high light plots, 643 to $756 \mu \mathrm{mol} \mathrm{m} \mathrm{m}^{-2} \mathrm{~s}^{-1}$ for medium light plots, and 413 to $523 \mu \mathrm{mol} \mathrm{m} \mathrm{m}^{-2} \mathrm{~s}^{-1}$ for low light plots. At Gaighat and Harnakachar, the PAR values ranged from 1065 to $1158 \mu \mathrm{mol} \mathrm{m} \mathrm{m}^{-2} \mathrm{~s}^{-1}$ for high light plots, 810 to $943 \mu \mathrm{mol} \mathrm{m} \mathrm{m}^{-2} \mathrm{~s}^{-1}$ for medium light plots, and 629 to $736 \mu \mathrm{mol} \mathrm{m} \mathrm{m}^{-2} \mathrm{~s}^{-1}$ for low light plots. At Ranitali, the PAR values ranged from 1200 to $1310 \mu \mathrm{mol} \mathrm{m} \mathrm{m}^{-2} \mathrm{~s}^{-1}$ for high light plots, 923 to $1056 \mu \mathrm{mol} \mathrm{m} \mathrm{m}^{-2} \mathrm{~s}^{-1}$ for medium light plots, and 743 to $833 \mu \mathrm{mol} \mathrm{m} \mathrm{m}^{-2} \mathrm{~s}^{-1}$ for low light plots.

\section{Study species}

Established seedlings of four species viz., A. catechu (Mimosaceae), B. retusa (Euphorbiaceae), L. parviflora (Lytheraceae), and S. robusta (Dipterocarpaceae) occurring at all the four study sites and differing in their life history traits (Table 2) were observed for various parameters. Nine seedlings of similar size were selected at each plot across the sites in each light level and tagged by small metallic plates and marked by a permanent 
marker. Light measurements (PAR), further denoted as $\mathrm{LT}_{\mathrm{a}}$, were taken near the tagged seedlings every month during the photosynthetic measurements (see Fig. 2). Due to the abiotic and biotic disturbances during the experimental period, some seedlings across species and sites got damaged and the number of seedlings in each species was decreased to three per plot at the end of the 2 -year period (i.e., 18 per site).

\section{Soil characteristics}

Soil moisture content $\left(\mathrm{SMC}_{\mathrm{a}}\right.$, percentage by volume) was measured in five replicates, randomly at three locations at a depth of $10 \mathrm{~cm}$ during light measurements (September 2005) in each plot, at each site using a theta probe instrument (type ML 1, Delta-T Devices, Cambridge, UK). Monthly soil moisture $\left(\mathrm{SMC}_{\mathrm{b}}\right.$, percentage by volume) was recorded near the tagged seedlings, in triplicate for 2 years (i.e., July 2006 to June 2008) across sites. Composite surface $(0-30 \mathrm{~cm})$ soil samples were also collected for once, from those locations for physicochemical analysis. These samples were analyzed for texture (Sheldrick and Wang 1993), organic C (Walkley and Black 1934), total N (Bremner and Mulvaney), and total P (Olsen and Sommers 1982) contents. To get the actual organic carbon content, the values obtained by Walkley and Black method were multiplied by a correction factor (1.95) given by Krishan et al. (2009), which was used for similar soils of central India. Soil bulk density at each site was determined by the core method (Krzic et al. 2000).

\section{Seedling growth and leaf attributes}

Height $(H)$ and stem diameter $(D) 10 \mathrm{~cm}$ above the ground for the 10 tagged seedlings were measured initially in July 2006. Area-based photosynthetic rate $\left(A_{\text {area }}\right)$ and area-based stomatal conductance $\left(\mathrm{Gs}_{\text {area }}\right)$ were estimated monthly on a healthy and fully expanded leaf of each tagged seedling with an LC Pro Console Photosynthetic meter (model EN11 ODB, ADC Bioscientific Ltd. UK) between 09:30 and 11:30 am under ambient conditions.
Other leaf traits were estimated, by sampling 10 healthy and fully expanded leaves each month from the seedlings visually comparable with the tagged ones and growing in the similar light condition from each plot, and pooled to obtain one per plot or nine samples per site. Leaf area was recorded with a leaf area meter (SYST RONICS Leaf Area Meter-211, India). These leaves were marked and sealed in plastic bags containing damp paper towel and carried to the laboratory for further analysis. One leaf from the collected sample of each light level was kept separately in an ice box for estimation of leaf chlorophyll.

Chlorophyll was analyzed by crushing $0.1 \mathrm{~g}$ of the leaf in $10 \mathrm{ml} \mathrm{80 \%}$ acetone (Arnon 1949). The absorbance $(D)$ of the extract was then measured at 645 and $663 \mathrm{~nm}$ using $80 \%$ acetone as blank.

Among the eight leaf attributes, SLA, Chl, $\mathrm{Gs}_{\text {area }}$, and $A_{\text {area }}$ were measured every month, whereas LDMC, LNC, and LPC were estimated four times in a year (i.e., seasonal) by compositing the powdered leaf samples for 3 months in a season for each light level across sites.

Fresh leaves were oven dried at $60{ }^{\circ} \mathrm{C}$ for $72 \mathrm{~h}$ to obtain the dry weight. LDMC was estimated by watersaturated fresh weight of the leaf and its dry weight. LNC was estimated using the Kjeldahl technique (Bradstreet 1965) and LPC using the phosphomolybdic blue colorimetric method (Anderson \& Ingram 1993). LNC and LPC are the total amounts of nitrogen and phosphorus, respectively, per unit dry leaf mass, expressed as percentage dry weight. The abovementioned attributes were measured, in general, according to the protocol of Cornelissen et al. (2003).

\section{Data analysis}

Above-ground biomass of seedlings for each season was estimated non-destructively using the allomatric equation relating height $(H)$, above-ground biomass (AGB), and wood specific gravity $(\rho)\{Y=3.428+0.310 X ; Y=$ logarithm of above ground biomass (lnAGB); $X=$ $\left.\ln \left(\rho D^{2} H\right)\right\}$ given by Chaturvedi et al. (2012). RGR of seedlings was calculated using equation: $R G R=(\ln$ $\left.\mathrm{AGB}_{2}-\mathrm{AGB}_{1}\right) /\left(t_{2}-t_{1}\right)$, where $\mathrm{AGB}_{1}$ and $\mathrm{AGB}_{2}$ are

Table 2 Characteristics of selected species based on Troup (1921), Verma et al. (1993), and Singh et al. (2003)

\begin{tabular}{|c|c|c|c|c|}
\hline Parameter & Acacia catechu & Briedelia retusa & Lagerstroemia parviflora & Shorea robusta \\
\hline Height & Moderate & Moderate & Large & Large \\
\hline Leaf phenology & Highly deciduous & Short-deciduous & Short-deciduous & Semi-evergreen \\
\hline Drought tolerance & High & Low & Moderate & Very low \\
\hline Light preference & Strong light demander & Shade tolerant & Light demander & Shade tolerant \\
\hline Seedling growth & Fast & Slow & Moderate & Moderate \\
\hline Soil & Sandy and gravelly loam & Sandy loam & Loam & Porous loam \\
\hline Habitat preference & Dry deciduous forest & Mixed dry tropical forest & Mixed dry tropical forest & Moist deciduous forest \\
\hline
\end{tabular}




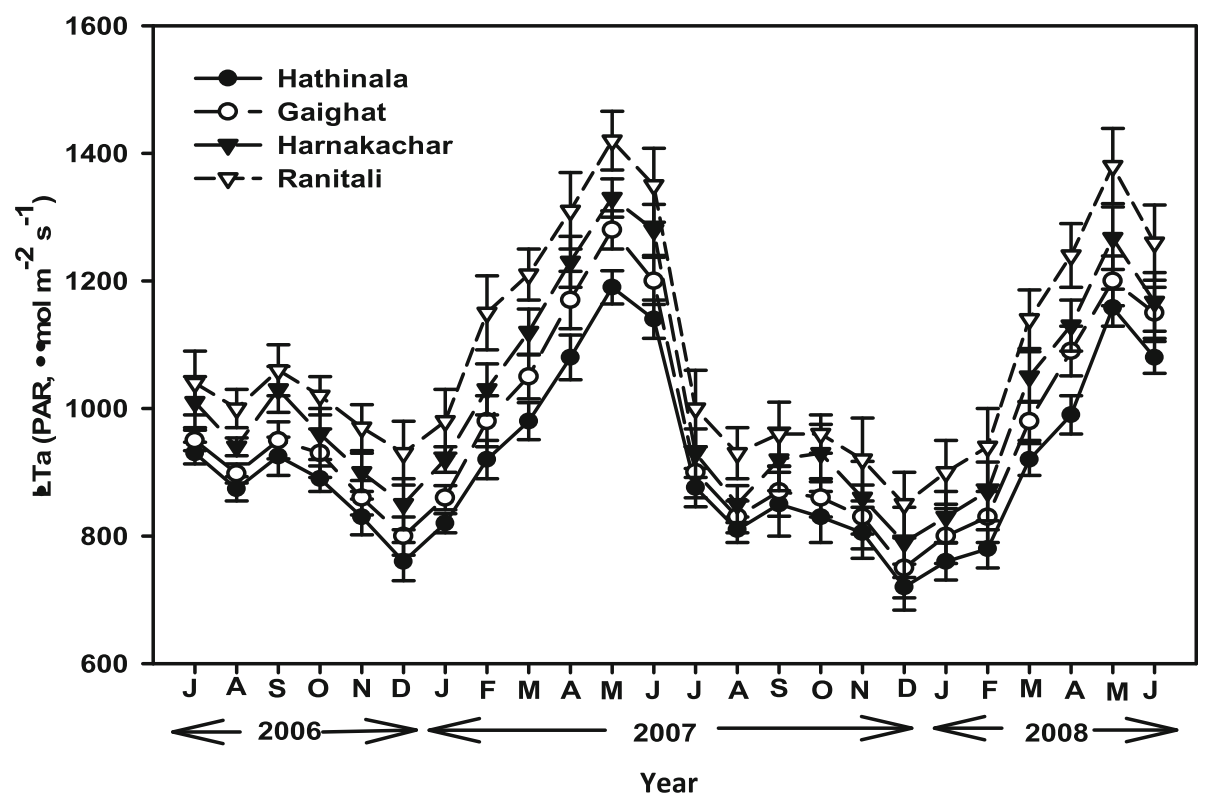

Fig. 2 Variation in the availability of light (LTa, PAR; mean and S.E.) across seasons, sites, and canopy conditions measured for a period of 2 years

initial and final above-ground biomass and $t_{1}$ and $t_{2}$ are initial and final time period, respectively. Gs $s_{\text {area }}$ and $A_{\text {area }}$ were converted to $\mathrm{Gs}_{\text {net }}\left(=\mathrm{Gs}_{\text {mass }}\right.$, mass-based stomatal conductance) and $A_{\text {net }}$ ( $=A_{\text {mass }}$, mass-based photosynthetic rate) with the help of SLA. The average seasonal leaf trait values of each species in nine plots were considered as replicates for a site. At the end of the study period of 2 years, the total number of data points for each leaf attribute and RGR was $1152(n=9$ replicates $\times$ 4 species $\times 4$ sites $\times 4$ seasons $\times 2$ years).

Data related to leaf attributes and RGR were analyzed by repeated measures analysis of covariance with light as covariate. Tukey's post hoc test was applied to estimate the differences between the mean values of leaf attributes. Associations among leaf attributes and RGR were observed by calculating Pearson's correlation coefficients (two-tailed). Regression analysis was done to estimate the effect of variability of light on leaf attributes and RGR. Slope of the regression line was taken as a measure of plasticity (Valladares et al. 2006). All the statistical analysis was performed with SPSS (Statistical Packages for the Social Sciences) software (ver. 16; SPSS Inc, Chicago, Illinois).

\section{Results}

\section{Soil properties}

Hathinala site was the moistest site with a mean annual SMC of $14.4 \%$ and Ranitali was the driest having annual SMC of $8 \%$ (Table 1). There was a marked seasonal variation of SMC among sites, ranging from $26.2 \%$ in monsoon season at Hathinala to $3.1 \%$ in early post-monsoon season at Ranitali. Soil moisture (measured across sites in September 2005) showed a significant positive association with $\mathrm{pH}$, organic carbon, total nitrogen, total phosphorus, and clay content, while its relationship was nonsignificant with bulk density of soil, and negatively scaled with sand content (Table 3). There was a strong negative correlation between the SMC and light availability (Table 3); shady conditions demonstrated higher moisture content as compared to the open canopies (Table 2). The moistest site Hathinala exhibited higher $\mathrm{pH}$, organic carbon, total nitrogen, total phosphorus, and clay content relative to the driest site Ranitali, where sand content was more (Table 1).

\section{Light regimes under closed, intermediate, and open canopy}

Light conditions $\left(\mathrm{LT}_{\mathrm{a}}\right)$ measured for 2 years across seasons and sites were significantly different under closed, intermediate, and open canopy plots $\left(F_{2,3072}=244, P<\right.$ 0.001 ). Across years and seasons, the values of PAR averaged for three plots under open, medium, and closed canopy were lowest at Hathinala site and greatest at Ranitali site (Fig. 2). The other two sites (Gaighat and Harnakachar) exhibited intermediate response and their PAR values ranged between Hathinala and Ranitali sites (Fig. 2). Across seasons, sites, and species, the highest mean value of $\mathrm{LT}_{\mathrm{a}}$ was observed in pre-rainy season and lowest in early post-rainy season.

\section{Leaf attributes across species, sites, and season}

Repeated measures ANCOVA indicated significant effects of season, site, and species for all leaf attributes. The interactions, season $\times$ site, season $\times$ species, and site 
Table 3 Pearson correlation coefficients between soil properties across experimental sites and light conditions

\begin{tabular}{|c|c|c|c|c|c|c|c|c|c|}
\hline & Light & SMC & Bulk density & $\mathrm{pH}$ & Organic C & Total N & Total P & Clay & Silt \\
\hline SMC & $-0.91^{* * *}$ & & & & & & & & \\
\hline $\mathrm{BD}$ & $0.37^{*}$ & $-0.12^{\mathrm{ns}}$ & & & & & & & \\
\hline $\mathrm{pH}$ & $-0.88^{* * *}$ & $0.85^{* * *}$ & $-0.28^{\text {ns }}$ & & & & & & \\
\hline C & $-0.77^{* * *}$ & $0.89^{* * *}$ & $0.042^{\mathrm{ns}}$ & $0.71^{* * *}$ & & & & & \\
\hline N & $-0.89^{* * *}$ & $0.90^{* * *}$ & $-0.13^{\mathrm{ns}}$ & $0.79^{* * *}$ & $0.93^{* * *}$ & & & & \\
\hline P & $-0.87^{* * *}$ & $0.87^{* * * *}$ & $-0.14^{\mathrm{ns}}$ & $0.91^{* * * *}$ & $0.86^{* * *}$ & $0.93^{* * * *}$ & & & \\
\hline Clay & $-0.80^{* * *}$ & $0.91^{* * *}$ & $0.03^{\mathrm{ns}}$ & $0.84^{* * *}$ & $0.92^{* * *}$ & $0.91^{* * *}$ & $0.94^{* * *}$ & & \\
\hline Silt & $-0.41^{*}$ & $0.59^{* * *}$ & $0.41^{*}$ & $0.32^{\text {ns }}$ & $0.72^{* * * *}$ & $0.62^{* * *}$ & $0.53^{* *}$ & $0.65^{* * *}$ & \\
\hline Sand & $0.68^{* * *}$ & $-0.83^{* * *}$ & $-0.23 \mathrm{~ns}$ & $-0.65^{* * *}$ & $-0.91^{* * *}$ & $-0.85^{* * *}$ & $-0.82^{* * *}$ & $-0.92^{* * *}$ & $-0.89^{* * *}$ \\
\hline
\end{tabular}

$\times$ species were also significant for all the attributes. Effects of year, year $\times$ season, and year $\times$ site were not significant for $\mathrm{Gs}_{\text {net }}, \mathrm{Chl}$, and $A_{\text {net }}$ respectively (Table 4). All leaf attributes showed higher mean values in the second year except LDMC. Across sites, the mean values of all leaf attributes, except LDMC, were the highest at Hathinala (SLA, $116.8 \mathrm{~cm}^{2} \mathrm{~g}^{-1}$; LNC, $1.58 \%$; LPC, $0.15 \%$; Chl, $0.93 \mathrm{mg} \mathrm{g}^{-1} ; \mathrm{G}_{\text {net }}, 2.32 \mathrm{mmolg}^{-1} \mathrm{~s}^{-1} ; A_{\text {net }}, 85.6$ $\mathrm{nmolg}^{-1} \mathrm{~s}^{-1}$; RGR, $0.035 \mathrm{~g} \mathrm{~g}^{-1}$ year $\left.^{-1}\right)$. LDMC was the highest at Ranitali site (37.7\%) (Fig. 3).

Across seasons, LNC, LPC, and Chl showed the highest mean value in the rainy season (LNC, $2.1 \%$; LPC, $0.18 \%$; and Chl, $1.63 \mathrm{mg} \mathrm{g}^{-1}$ ); SLA was higher in the pre-rainy season $\left(129.2 \mathrm{~cm}^{2} \mathrm{~g}^{-1}\right)$ and LDMC was highest in the early post-rainy season (45.8\%) (Fig. 3). Maximum mean values of $\mathrm{Gs}_{\text {net }}\left(5.3 \mathrm{mmol} \mathrm{g}^{-1} \mathrm{~s}^{-1}\right), A_{\text {net }}\left(188.5 \mathrm{nmol} \mathrm{g}^{-1} \mathrm{~s}^{-1}\right)$, and RGR (0.08 $\mathrm{mg} \mathrm{g}^{-1}$ month $\left.^{-1}\right)$, across years and sites, were observed in the rainy season (Fig. 4). An additional file represents this information in more detail (Additional file 1).

Across species, S. robusta displayed the highest mean value of SLA (147.2 $\left.\mathrm{cm}^{2} \mathrm{~g}^{-1}\right)$, LDMC (41.3\%), LNC (1.9\%), LPC (0.13\%), and Chl (0.88 $\left.\mathrm{mg} \mathrm{g}^{-1}\right)$ (Fig. 3).

In the three light levels, SLA varied 2.2 fold, LDMC 1.5 fold, LNC 1.9 fold, LPC 1.7 fold, Chl 1.4 fold, Gs 2.1 fold, $A_{\text {net }} 2.4$ fold, and RGR 5.3 fold. Species-wise variations in response to the availability of light were also significant (Fig. 5). S. robusta and B. retusa demonstrated highest mean values for all the leaf attributes (except LDMC) in low light. A. catechu showed the highest mean values for LDMC, LNC, LPC, Gs ${ }_{\text {net }}, A_{\text {net }}$, and RGR in high light, and the highest values for SLA and Chl in low-light condition. L. parviflora registered the highest mean value of LDMC in high light; LNC, LPC, $\mathrm{Gs}_{\text {net }}$, $A_{\text {net, }}$ and RGR in moderate light, and SLA and Chl in low light (Fig. 5). Among species maximum variation in leaf attributes in relation to the highest and lowest level of light availability was exhibited by $A$. catechu at Hathinala in rainy season (SLA varied 2.8 fold, LDMC 1.6 fold, LNC 2.1 fold, LPC 1.8 fold, Chl 2.1 fold, Gs net $_{3.2}$ fold, $A_{\text {net }} 3.1$ fold, and RGR 5.6 fold), and lowest variation was demonstrated by $B$. retusa at the same site (SLA 1.6 fold, LDMC 1.2fold, LNC 1.5 fold, LPC 1.2 fold, Chl 1.5 fold, Gs net $_{2.1}$ fold, $A_{\text {net }} 2.2$ fold, and RGR 2.8 fold). For all species, minimum variation in the mean values of leaf attributes at high light as compared to low light in the rainy season was observed at Ranitali, where S. robusta demonstrated maximum variation in leaf attributes (SLA 1.5 fold, LDMC 1.4 fold, LNC 1.4 fold, LPC 1.2 fold, Chl 1.4 fold, $\mathrm{Gs}_{\text {net }} 1.9$ fold, $\mathrm{A}_{\text {net }} 1.8$ fold, and RGR 1.9 fold), whereas the minimum variation was observed in $A$. catechu (SLA 1.1 fold, LDMC 1.1 fold, LNC 1.2 fold, LPC 1.1 fold, Chl 1.1 fold, $G_{\text {net }} 1.4$ fold, $A_{\text {net }} 1.3$

Table 4 Summary of repeated measures ANCOVA, with light $\left(\mathrm{LT}_{1}\right)$ as covariate, on functional attributes of seedlings of four tropical dry forest tree species (only main effects and two-way interactions are shown)

\begin{tabular}{lllllllll}
\hline Subject & SLA & LDMC & LNC & LPC & Chl & Gs net & $A_{\text {net }}$ & RGR \\
\hline SS & $4383^{* * *}$ & $3072^{* * *}$ & $2568^{* * *}$ & $9.3^{* *}$ & $3668^{* * *}$ & $3349^{* * *}$ & $2071^{* * *}$ & $2663^{* * *}$ \\
ST & $20.8^{* * *}$ & $635.6^{* * *}$ & $13.06^{* * *}$ & $8.68^{* * *}$ & $92.96^{* * *}$ & $94.4^{* * *}$ & $17.8^{* * *}$ & $18.4^{* * *}$ \\
SP & $589.7^{* * *}$ & $7521^{* * *}$ & $2271^{* * *}$ & $5.67^{* *}$ & $104.6^{* * *}$ & $1904^{* * *}$ & $1006^{* * *}$ & $115.9^{* * *}$ \\
SS $\times$ ST & $230^{* * *}$ & $13000^{* * *}$ & $138^{* * *}$ & $8.72^{* * *}$ & $652^{* * *}$ & $454^{* * *}$ & $172.8^{* * *}$ & $19.05^{* * *}$ \\
SS $\times$ SP & $1770^{* * *}$ & $15700^{* * *}$ & $2971^{* * *}$ & $4.6^{* *}$ & $2886^{* * *}$ & $848.5^{* * *}$ & $1650^{* * *}$ & $145.7^{* * *}$ \\
ST $\times$ SP & $4.40^{* * *}$ & $214^{* * *}$ & $35.5^{* * *}$ & $7.57^{* * *}$ & $73.65^{* * *}$ & $22.28^{* * *}$ & $11^{* * *}$ & $16.67^{* * *}$ \\
\hline
\end{tabular}

The residual df is 415. YR, year; ST, site; SS, season; SP, species; SLA, specific leaf area; LDMC, leaf dry matter content; LNC, leaf nitrogen concentration; LPC, leaf phosphorus concentration; Chl, chlorophyll concentration; $\mathrm{Gs}_{\text {net }}\left(=\mathrm{Gs}_{\text {mass, }}\right.$ mass-based stomatal conductance); $A_{\text {net }}\left(=A_{\text {mass, }}\right.$ mass-based photosynthetic rate); RGR, relative growth rate. ${ }^{* *} P<0.01,{ }^{* * *} P<0.001$ 

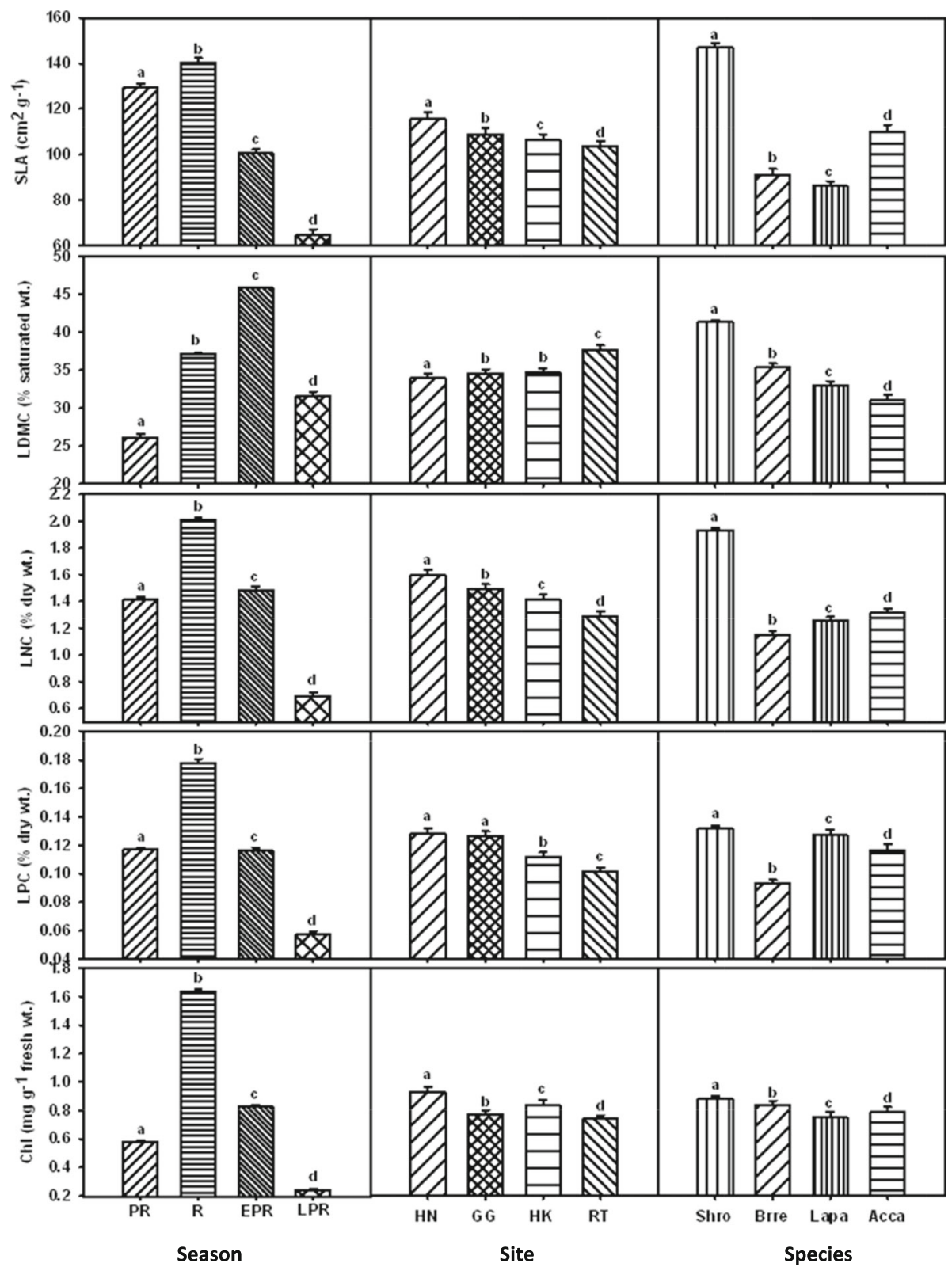

Fig. 3 Mean values of leaf traits across sites, seasons, and species. SLA, specific leaf area; LDMC, leaf dry matter content; LNC, leaf nitrogen concentration; LPC, leaf phosphorus concentration; Chl, chlorophyll concentration; HN, Hathinala; GG, Gaighat; HK, Harnakachar; RT, Ranitali; PR, pre-rainy; R, rainy; EPR, early post-rainy; LPR, late post-rainy; Shro, Shorea robusta; Brre, Briedelia retusa; Lapa, Lagerstroemia parviflora; Acca, Acacia catechu. Narrow bars represents 1 S.E. Different letters above the bars indicate significant differences after Tukey's post hoc test $(a=0.05)$

fold, RGR 1.2 fold). An additional file represents this information in more detail (Additional file 1).

\section{Relationships among leaf attributes}

Leaf attributes exhibited significant correlations across species, season, sites, and light levels, except for the association of LDMC with LPC which was statistically not significant (Table 5). LDMC was negatively associated with SLA and RGR. RGR showed significant positive relationships with other leaf attributes, except with LDMC.
It was observed that the relationships of LDMC with RGR was not significant in other seasons; however, in the late post-monsoon season, it was statistically significant $\left(r=0.19^{*}, P<0.05\right)$.

\section{Relationships of leaf attributes with light}

For all species, light intensity significantly affected all leaf attributes, except SLA, LNC, and LPC in L. parviflora and LDMC in all species, except S. robusta. SLA was negatively scaled with increasing light levels, while 


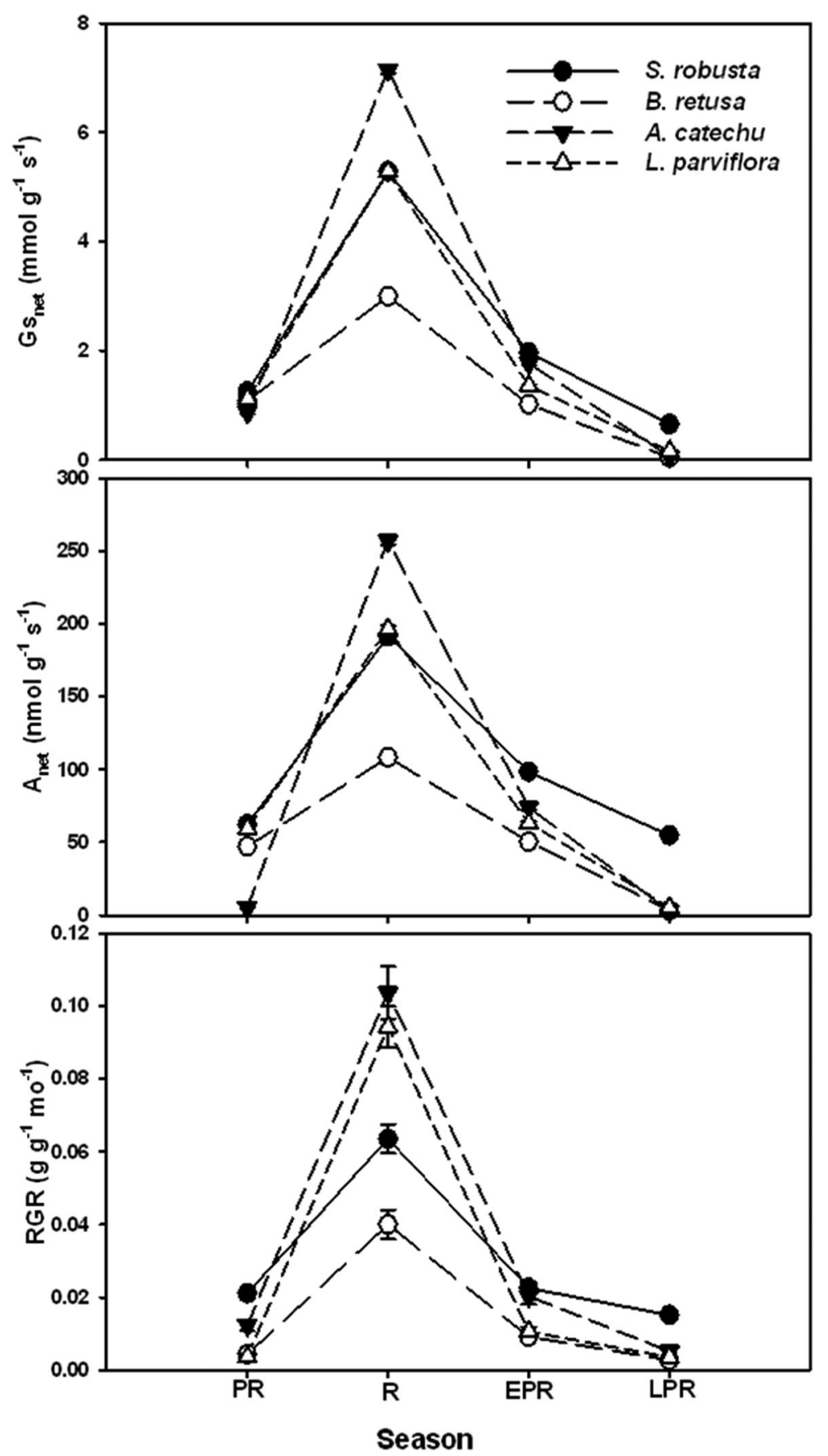

Fig. 4 Seasonal variations in leaf attributes and relative growth rates (RGR) in four dry tropical tree species across four sites. Gs $s_{\text {net, }}$ net stomatal conductance; $A_{\text {net, }}$, net photosynthetic rate; PR, pre-rainy; $R$, rainy; EPR, early post-rainy; LPR, late post-rainy

LDMC exhibited positive association with light availability across species. LNC and LPC were correlated positively with enhanced light in $A$. catechu, whereas this relationship was negative in $B$. retusa and $S$. robusta. Chl was negatively scaled with higher light availability across species. $\mathrm{Gs}_{\text {net }}, A_{\text {net }}$, and RGR have shown a positive relationship with increased light in $A$. catechu and B. retusa, while this trend was negative in case of $B$. retusa and $S$. robusta (Table 6).

Across species, the variability in light interpreted $6 \%$ (L. parviflora) to $23 \%$ (A. catechu) of the variability in SLA. In case of LDMC, lowest variability (5\%) was explained for B. retusa, whereas highest (14\%) for S. robusta. Greatest variability in LNC (20\%), LPC 


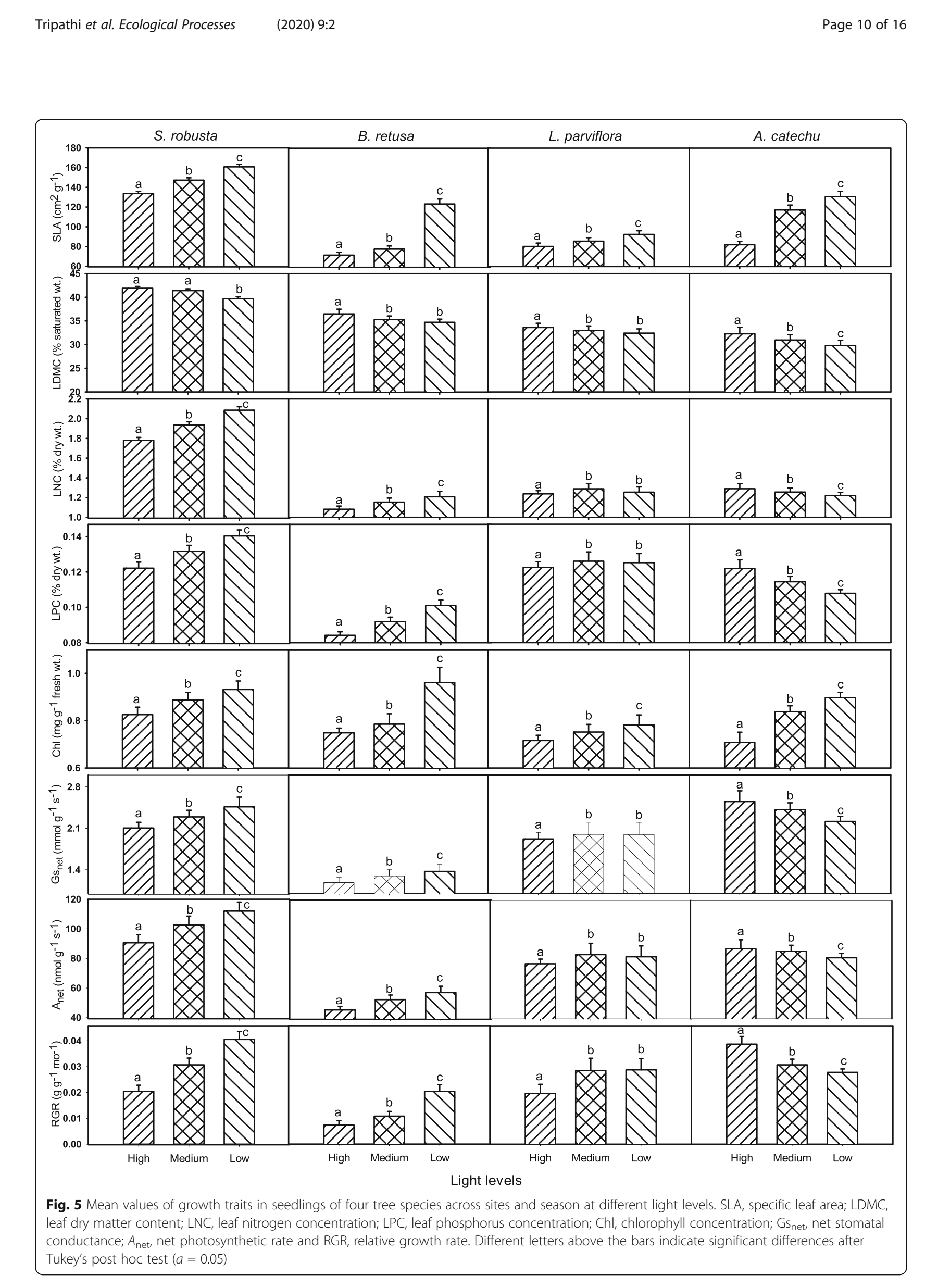


Table 5 Pearson correlation coefficients between $\mathrm{SMC}_{1}$ and functional attributes across species, sites, seasons, and light levels

\begin{tabular}{|c|c|c|c|c|c|c|c|c|}
\hline & $\mathrm{SMC}_{1}$ & SLA & LDMC & LNC & LPC & Chl & $\mathrm{Gs}_{\text {net }}$ & $A_{\text {net }}$ \\
\hline SLA & $0.47^{* * *}$ & & & & & & & \\
\hline LDMC & $-0.10^{* *}$ & $-0.07^{*}$ & & & & & & \\
\hline LNC & $0.56^{* * *}$ & $0.80^{* * *}$ & $0.12^{* *}$ & & & & & \\
\hline LPC & $0.10^{* *}$ & $0.07^{*}$ & $0.02^{\mathrm{ns}}$ & $0.08^{* *}$ & & & & \\
\hline $\mathrm{Chl}$ & $0.75^{* * *}$ & $0.63^{* * *}$ & $0.15^{* *}$ & $0.76^{* * *}$ & $0.07^{*}$ & & & \\
\hline $\mathrm{Gs}_{\text {net }}$ & $0.78^{* * *}$ & $0.53^{* * *}$ & $0.11^{* *}$ & $0.71^{* * *}$ & $0.09^{* *}$ & $0.87^{* * *}$ & & \\
\hline$A_{\text {net }}$ & $0.74^{* * *}$ & $0.56^{* * *}$ & $0.08^{* *}$ & $0.76^{* * *}$ & $0.09^{* *}$ & $0.84^{* * *}$ & $0.97^{* * *}$ & \\
\hline$R G R$ & $0.67^{* * *}$ & $0.44^{* * *}$ & $0.05^{\mathrm{ns}}$ & $0.58^{* * * *}$ & $0.06^{*}$ & $0.70^{* * *}$ & $0.80^{* * *}$ & $0.79^{* * * *}$ \\
\hline
\end{tabular}

$\mathrm{SMC}_{1}$, soil moisture content; SLA, specific leaf area; LDMC, leaf dry matter content; LNC, leaf nitrogen concentration; LPC, leaf phosphorus concentration; Chl, chlorophyll concentration; $\mathrm{Gs}_{\text {net }}\left(=\mathrm{Gs}_{\text {mass }}\right.$ mass-based stomatal conductance); $A_{\text {net }}\left(=A_{\text {mass, }}\right.$ mass-based photosynthetic rate); $\mathrm{RGR}$, relative growth rate. $n=1152$, ${ }^{n s} P>0.05,{ }^{*} P<0.05,{ }^{* *} P<0.01, * * * P<0.001$

(15\%), and Chl (22\%) was explained for A. catechu compared to other three species. Variability in light interpreted the highest amount of variability in $\mathrm{Gs}_{\text {net }}(31 \%), \mathrm{A}_{\text {net }}$ (29\%), and RGR (38\%) in A. catechu (Table 6).

The slope of light and trait relationship showed plasticity in study species (Table 6). Across species, A. catechu exhibited highest slope for all attributes, except LDMC, which exhibited the greatest slope in case of S. robusta. Slope for Chl was lowest in S. robusta and highest in A. catechu. Lowest slope for SLA, LNC, $A_{\text {net, }}$ and RGR was in case of $L$. parviflora, whereas for LDMC it was lowest in $B$. retusa.

\section{Discussion}

The pronounced seasonality of rainfall in TDF directly determine the soil moisture availability and plays an important role in the germination, growth, and survival of tree seedlings (Khurana and Singh 2001b; McLaren and MA 2003; Marod et al. 2004). Seedlings, being the most vulnerable stage in the life cycle of trees, face a plethora of heterogeneity during the most favorable growth season (i.e., rainy season) when the ample availability of water and nutrient may not be harvested efficiently, due to the reduced irradiance, modified quality of light, and filtering effect of the canopy (Huante and Rincón 1998; Khurana and Singh 2006; Bhadouria et al. 2017b). The shady and open habitats in the TDF not only differ in light conditions but also the temperature, humidity, and soil moisture availability (Huante and Rincón 1998). In the present study, lower light availability has significantly lowered the physiological rates and RGR across species, although differentially; but during

Table 6 Parameters of regression equations $(y=a+b x)$ relating functional attributes $(y)$ of four tree species with $\mathrm{LT}_{a}(x)$

\begin{tabular}{|c|c|c|c|c|c|c|c|c|c|}
\hline & $a$ & $b$ & $R^{2}$ & $a$ & $b$ & $R^{2}$ & $a$ & $b$ & $R^{2}$ \\
\hline & SLA & & & LDMC & & & LNC & & \\
\hline A. catechu & 46.4 & -3.9 & $0.23^{* * *}$ & 32.4 & 0.08 & $0.03^{\mathrm{ns}}$ & 0.34 & 0.03 & $0.20^{* * *}$ \\
\hline B. retusa & 55.6 & -1.6 & $0.13^{* *}$ & 21.2 & 0.05 & $0.02^{\mathrm{ns}}$ & 0.45 & -0.02 & $0.14^{* *}$ \\
\hline L. parviflora & 57.2 & -1.1 & $0.06^{\mathrm{ns}}$ & 35.2 & 0.06 & $0.03^{\mathrm{ns}}$ & 0.57 & 0.005 & $0.04^{\mathrm{ns}}$ \\
\hline S. robusta & 86.4 & -1.8 & $0.18^{* * *}$ & -48.8 & 0.13 & $0.14^{* *}$ & 0.89 & -0.02 & $0.13^{* *}$ \\
\hline LPC & & & & Chl & & & $G s_{n e t}$ & & \\
\hline A. catechu & -0.009 & 4.6 & $0.15^{* *}$ & 0.05 & -0.05 & $0.22^{* * *}$ & 1.37 & 0.18 & $0.31^{* * *}$ \\
\hline B.retusa & 0.007 & -2.3 & $0.08^{*}$ & 0.02 & -0.02 & $0.15^{* *}$ & 0.32 & -0.11 & $0.14^{* *}$ \\
\hline L. parviflora & 0.008 & 1.6 & $0.04^{\mathrm{ns}}$ & 0.03 & -0.03 & $0.18^{* * *}$ & -0.44 & 0.12 & $0.10^{*}$ \\
\hline S. robusta & 0.01 & -1.9 & $0.09^{*}$ & 0.31 & -0.01 & $0.14^{* *}$ & 0.21 & -0.15 & $0.21^{* * *}$ \\
\hline$A_{\text {net }}$ & & & & RGR & & & & & \\
\hline A. catechu & -48.4 & 8.3 & $0.29^{* * *}$ & -0.05 & 4.1 & $0.38^{* * *}$ & & & \\
\hline B.retusa & 11.3 & -2.3 & $0.12^{* *}$ & 0.01 & -2.1 & $0.18^{* * *}$ & & & \\
\hline L. parviflora & -7.9 & 1.9 & $0.09^{*}$ & 0.02 & 1.5 & $0.11^{*}$ & & & \\
\hline S. robusta & 25.0 & -3.8 & $0.19^{* * *}$ & 2.3 & -3.0 & $0.25^{* * *}$ & & & \\
\hline
\end{tabular}

SLA, specific leaf area; LDMC, leaf dry matter content; LNC, leaf nitrogen concentration; LPC, leaf phosphorus concentration; Chl, chlorophyll concentration; Gsnet (= Gsmass, mass-based stomatal conductance); Anet (= Amass, mass-based photosynthetic rate); RGR, relative growth rate. ${ }^{\text {ns }} P>0.05,{ }^{*} P<0.05,{ }^{* *} P<0.01,{ }^{* * *} P$ $<0.001$ 
the driest pre-rainy season (summer), shady habitats played a vital role in promoting the survival of seedlings across species. This is in agreement with our hypothesis (hypothesis-1) and other studies performed in TDFs (McLaren and McDonald 2003). Lebrija-Trejos et al. (2011) suggested that the environmental seasonality strongly affects the plant establishment and development, either by modulating spatial heterogeneity (Hennenberg et al. 2008) or by interacting with it to provide conditions that may be promoting in one season but suppressing in another (Warren 2008).

Leaf attributes vary systematically with a species' juvenile light requirement (Valladares and Niinemets 2008). Leaves exhibit a remarkable ability to acclimatize in variable environmental conditions by acquiring plasticity in morphological, anatomical, and physiological traits (Valladares et al. 2007). The leaf attributes studied in the present study were significantly influenced by season, site, species, and their interactions. The impact of seasonality was more pronounced compared to the other two factors, suggesting that the effect of heterogeneity in light availability during the rainy season (i.e., growth season) on seedling growth was stronger. This is in conformity with other studies (Marod et al. 2004; Craven et al. 2011). Craven et al. (2011) reported that species vary in their photosynthetic rate seasonally, and demonstrated adaptive capacity to regulate leaf photosynthesis between wet and dry seasons. In this study, shadetolerant $S$. robusta showed greater variation in the values of leaf attributes than that of light-demanding species, particularly at the driest site in the pre-rainy season. This is in agreement with our hypothesis (hypothesis-2), which is in conformity with Craven et al. (2011), where the species-wise variation in photosynthetic traits was higher in the dry season.

SLA, LDMC, and RGR are good proxies of plant resource-use strategy (Cornelissen et al. 2003; Weiher et al. 1999), and they are well accepted representatives of the global leaf economic spectrum (Diaz et al. 2004; Wright et al. 2004). In the present study, SLA was significantly higher in closed canopy plots across seasons, which is in agreement with other studies (Osunkoya et al. 1994; Kitajima 1994). The modulation in SLA has been reported to allow efficient light harvesting to improve photosynthetic efficiency in low-light conditions (Reich et al. 1997; Kitao et al. 2000), and therefore allowing the plant to maintain a positive carbon balance (Kitajima 1994; Valladares et al. 2000). LDMC was considerably low in low-light condition during the rainy season; however, LDMC tended to be lower in other seasons as well under shady conditions relative to medium and high light levels. Kröber et al. (2012) reported a significant decrease in LDMC in response to shade, whereas Markesteijn et al. (2007) estimated higher LDMC in sun leaves.

Among species, RGR of seedlings was suppressed in low light condition, particularly during the rainy season when the availability of light at the forest floor was poor; however, species varied in their response. Greatest suppression in RGR at low light was observed in A. catechu, a strong light demander, while the lowest decline was reported in $S$. robuta, a shade-tolerant species at the moistest site Hathinala. Overall, A. catechu has performed well in high-light condition, while vice versa was in S. robusta. Rincon and Huante (1993) reported that the light-demanding and pioneer species were more responsive to higher light availability, demonstrating high RGR relative to shade tolerants.

Leaf N, Leaf $\mathrm{P}$, and Chl tended to be higher in lowlight conditions in all species except $A$. catechu, which showed highest leaf nitrogen and phosphorus content in high-light condition; however, this trend was more prominent in rainy season across sites. Terashima et al. (2006) reported that high-leaf nitrogen content on a mass basis amplifies carbon assimilation by increasing the enzymes and other proteins involved in light capture (i.e., Chlorophyll a and b), light conversion (i.e., cytochrome $\mathrm{f}$, plastoquinone, plastocyanin, and ferredoxin), and carbon fixation (i.e., Rubisco and related enzymes of the Calvin cycle). Cannell and Thornley (2000) suggested that a higher leaf $\mathrm{N}$ on mass basis is directly related with higher growth rates and associated maintenance respiration, indicating the ecological limitations in the plasticity of these traits (Valladares et al. 2007). Further, under variable light conditions, leaves are expected to acclimatize by diversifying the $\mathrm{N}$ allocation to various leaf functions (Hikosaka 2004; Delagrange 2011). For example, under higher light availability, more nitrogen would be allocated to carbon fixation and electron transport as light harvesting is not limiting (Niinemets et al. 1998). However, under limiting light conditions, where priority changes to efficient light acquisition, greater $\mathrm{N}$ allocation would be in chlorophyll and other light harvesting pigments at the cost of enzymes involved in carboxylation and electron transport (Frak et al. 2001; Evans and Poorter 2001; Hikosaka 2004). Other studies also reported that, within species, shade-growing leaves are thinner, have lower leaf mass per unit area, and have higher massbased chlorophyll content than do sun-growing leaves (Popma and Bongers 1988; Kitajima 1994).

Physiological rates (i.e., $\mathrm{Gs}_{\text {net }}$ and $A_{\text {net }}$ ) studied were significantly higher in high-light conditions, while declined under low light, more strongly in the rainy season when the understorey light conditions were very poor. During the driest pre-rainy season, $\mathrm{Gs}_{\text {net }}$ and $A_{\text {net }}$ were greatest in closed canopy plots, comparatively 
more at drier sites across species. This may be due to the higher moisture availability in shady conditions during the dry season which facilitate stomatal conductance, leading in to a higher net photosynthetic rate (McLaren and MA 2003).

Irrespective of sites, season, species, and light levels, among the leaf attributes examined in this study, SLA was positively associated with LNC, LPC, Chl, Gs ${ }_{\text {net }}$, $A_{\text {net, }}$ and RGR, and negatively with LDMC. LDMC was negatively associated with RGR. However, the physiological traits $\mathrm{Gs}_{\text {net }}$ and $A_{\text {net }}$ were strongly and positively associated with SLA and RGR, while a weak relationship was evident with LDMC. The negative association of SLA and LDMC was more prominent during the rainy season, and therefore are in conformity with other studies, that increase in SLA is associated with decrease in LDMC (Garnier et al. 2001; Shipley and Vu 2002; Chaturvedi et al. 2012). However, during the driest season, this relationship was not significant statistically. The negative scaling of LDMC with RGR, particularly during the wet season is in line with other studies (Poorter and Bergkotte 1992; Chaturvedi et al. 2012). However, during the driest season, a weak positive association was observed between these two variables. In the present study, most of the leaf attributes significantly affect the RGR of studied species both alone and in combinations of light availability; however, the trend varied among species (hypothesis-3).

According to the concept of worldwide leaf economic spectrum, higher leaf mass per unit leaf area is related with lower LNC, LPC, Gs net, $A_{\text {net }}$, and RGR (Wright et al. 2004). Furthermore, net stomatal conductance and related intake of carbon dioxide significantly influence $A_{\text {net }}$ and largely depends on leaf structure (Wright et al. 2004). In the present study, LNC and Chl were positively scaled with $\mathrm{Gs}_{\text {net }}$ and $A_{\text {net }}$. Similarly, RGR was positively influenced by $\mathrm{Gs}_{\text {net }}$ and $A_{\text {net }}$, which implies that these representatives of leaf economic spectrum can be used to explain the variability in growth rate of tree seedlings in spatially and temporally heterogeneous environment of TDFs. Further, Hikosaka (2004) suggested that massbased leaf nitrogen content and photosynthetic rates are better means to explain inter-specific variation under varying resource availability.

Many studies have reported that leaves with high SLA and leaf $\mathrm{N}$ content demonstrate high nutrient concentration and $A_{\text {mass }}$ (Wright et al. 2004; Lambers et al. 2008; Kamiyama et al. 2010). On the contrary, leaves with low SLA are physically stronger and comparatively resistant to herbivory (Wright and Westoby 2002; Sterck et al. 2006). In present study, the highly deciduous and lightdemanding species $A$. catechu demonstrated higher SLA compared to the semi-evergreen and shade-tolerant $\mathrm{S}$. robusta. Lusk and Warton (2007) reported that in evergreen species, a low SLA is associated with shade tolerance. Further, in subtropical forests, SLA also indicates the difference between evergreen and deciduous leaf phenology (Kröber et al. 2012).

Differences in light availability has been claimed to induce a strong diverging plastic response among individual of the same species (Böhnke and Bruelheide 2013). Osunkoya et al. (1994) reported highest plasticity of most parameters in species that regenerate mostly in gaps and at forest edges and lowest in species that regenerate mostly in small gaps of forest understorey. However, in recent studies, it has been estimated that in TDFs light related plasticity in leaf attributes is of minor extent relative to wet forests, and more specifically correlated with the light requirements during ontogenic changes as in these forests soil moisture availability is major constraint for growth (Markesteijn et al. 2007). According to Valladares et al. (2006), slope of the regression line between a trait and an environmental variable can be used to explain the plasticity; the steeper the slope, the greater will be the plasticity in that trait. In the present study, species varied in plasticity of their leaf attributes in response to varying light conditions. A. catechu demonstrated highest leaf trait-related plasticity, having the highest slope values, whereas $B$. retusa displayed lowest plasticity with minimum slope values. The other two, S. robusta and L. parviflora, were intermediate in their response. This is in line with Böhnke and Bruelheide (2013), who reported the highest light-related plasticity in the most light-demanding and droughttolerant species, Q. velutina. Highest variability as explained by the variability in light condition was for $\mathrm{Gs}_{\text {net }}$ (31\%) and $\mathrm{A}_{\text {net }}(29 \%)$ in A catechu. The coefficient of determinant $\left(R^{2}\right)$ for LDMC was very low and nonsignificant in all species except $S$. robusta. This is in conformity with Kröber et al. (2012), where LDMC did not show a significant relationship with any of the environmental factor. The variability in the studied attributes as explained by the variability in light was lower as compared to what has been reported by Chaturvedi et al. (2012) in relation to soil moisture content, further confirming the results that light-related plasticity in TDF is of low extent over the plasticity associated with soil moisture availability (Markesteijn et al. 2007).

\section{Conclusion}

Our investigation suggests that seasonal variation in understorey light conditions plays an important role in determining the establishment and growth of tree seedlings in tropical dry forest. Severe light limitation in closed canopy habitats during the rainy season provides a growth constraint for seedlings of light-demanding pioneer species, thereby directly governing the species distribution and vegetation dynamics. Although to a lower 
extent, species component of the forest shows lightrelated plasticity in leaf attributes, which ultimately determines their fitness in a spatio-temporally heterogeneous environment of a seasonal tropical dry forest. Therefore, to generate a comprehensive understanding on the role of light availability on the growth and survival of tree species in tropical dry forests, long-term studies comprising of larger species components are of utmost importance.

\section{Supplementary information}

Supplementary information accompanies this paper at https://doi.org/10. 1186/s13717-019-0206-4.

Additional file 1: Table S1. Species wise mean values of leaf attributes and RGR. Table S2. Species and light level wise mean values of leaf attributes and RGR. Table S3. Species and season wise mean values of leaf attributes and RGR.

\section{Abbreviations}

$A_{\text {area: }}$ : Area-based photosynthetic rate; $A_{\text {net: }}$ Net photosynthetic rate; Chl: Leaf chlorophyll content; Gs area: Area-based stomatal conductance; Gs net: Net stomatal conductance; LDMC: Leaf dry matter content; LNC: Leaf nitrogen concentration; LPC: Leaf phosphorus concentration; PAR: Photosynthetically active radiation; RGR: Relative growth rate; SLA: Specific leaf area; SMC: Soil moisture content; SPSS: Statistical Packages for the Social Sciences; TDF: Tropical dry forest

\section{Acknowledgements}

SNT gratefully acknowledged the financial support provided by CSIR, New Delhi, India, in the form of research fellowship. Authors are highly thankful to the Head, Department of Botany, for providing necessary infrastructures for experimental analysis. Authors extend their gratefulness to the editor and anonymous reviewers for their suggestions and comments for improving the manuscript.

\section{Authors' contributions}

ASR and SNT designed the experiment. SNT and RB performed the experiment, processed the data, and performed statistical analyses. Manuscript was drafted by SNT, RSD, RB, and RKC which was finalized by SNT, ASR, PS, and RKC. All authors read and approved the final manuscript.

\section{Funding}

UGC, India; CSIR, India

\section{Availability of data and materials}

Not applicable

\section{Ethics approval and consent to participate}

Not applicable

\section{Consent for publication}

Not applicable

\section{Competing interests}

The authors declare that they have no competing interests.

\section{Author details}

${ }^{1}$ Ecosystems Analysis Laboratory, Department of Botany, Institute of Science, Banaras Hindu University, Varanasi 221005, India. ${ }^{2}$ Department of Botany, Deen Dayal Upadhyaya College, University of Delhi, New Delhi 110078, India. ${ }^{3}$ Natural Resource Management Laboratory, Department of Botany, University of Delhi, New Delhi 110007, India. ${ }^{4}$ Shyama Prasad Mukherjee Post-graduate College, University of Allahabad, Allahabad 211013, India. ${ }^{5}$ Xishuangbanna Tropical Botanical Garden, Chinese Academy of Sciences, Yunnan 666303, China. ${ }^{6}$ Institute of Environment and Sustainable Development (IESD) Banaras Hindu University, Varanasi 221005, India.
Received: 21 February 2019 Accepted: 20 November 2019

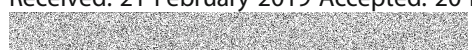

\section{References}

Anderson JM, Ingram JSI (1993) Tropical Soil Biology and Fertility: A Handbook of Methods. Wallingford, CT: CAB International, 221.

Anderson LJ, Maherali H, Johnson HB, Polley HW, Jackson RB (2001) Gas exchange and photosynthetic acclimation over sub-ambient to elevated $\mathrm{CO}_{2}$ in a C3-C4 grassland. Global Change Biol 7:693-707

Arnon DI. (1949) Copper enzymes in isolated chloroplasts, Polyphenoloxidase in Beta vulgaris. Plant Physiol 24:1-15.

Augspurger CK (1984) Light requirements of neotropical tree seedlings: a comparative study of growth and survival. J Ecol 72:777-795

Bhadouria R, Singh R, Srivastava P, Raghubanshi AS (2016) Understanding the ecology of tree-seedling growth in dry tropical environment: a management perspective. Energ Ecol Environ 1:296-309

Bhadouria R, Singh R, Srivastava P, Raghubanshi AS (2017b) Interactive effect of water and nutrient on survival and growth of tree seedlings of four dry tropical tree species under grass competition. Trop Ecol 58:611-621

Bhadouria R, Srivastava P, Singh R, Raghubanshi AS (2017a) Tree seedling establishment in dry tropics: an urgent need of interaction studies. Environ Syst Decis 37:88-100

Bhadouria R, Srivastava P, Singh S, Singh R, Raghubanshi A, Singh JS (2018) Effects of light, nutrient and grass competition on growth of seedlings of four tropical tree species. Indian Forester 144(1):54-65

Bhadouria R, Tripathi S, Srivastava P, Singh P (eds) (2020) Handbook of Research on the Conservation and Restoration of Tropical Dry Forests. IGI Global. https://doi.org/10.4018/978-1-7998-0014-9

Böhnke M, Bruelheide H (2013) How do evergreen and deciduous species respond to shade?-Tolerance and plasticity of subtropical tree and shrub species of South-East China. Environ Exp Bot 87:179-190

Bradstreet RB (1965) The Kjeldahl Method for Organic Nitrogen. Academic Press, New York, p 239

Bremner JM, Mulvaney CS (1982) Nitrogen total. In: Page AL, Miller RH, Keeney DR (eds) Methods of soil analysis: Part 2. Chemical and microbiological properties. Agronomy Monograph No. 9. (Second edition). American Society of Agronomy and Soil Science Society of America, Madison, WI, US, pp 595-624

Cannell MGR, Thornley JHM (2000) Modelling the components of plant respiration: some guiding principles. Ann Bot 85:45-54

Chaturvedi RK, Raghubanshi AS, Singh JS (2011) Effect of small-scale variations in environmental factors on the distribution of woody species in tropical deciduous forests of Vindhyan Highlands, India. J Bot 2011:297097. https:// doi.org/10.1155/2011/297097

Chaturvedi RK, Raghubanshi AS, Singh JS (2012) Growth of tree seedlings in a tropical dry forest in relation to soil moisture and leaf traits. J Plant Ecol 6: $158-170$

Coomes DA, Kunstler G, Canham CD, Wright E (2009) A greater range of shadetolerance niches in nutrient-rich forests: an explanation for positive richnessproductivity relationships? J Ecol 97:705-717

Cornelissen JHC, Cerabolini B, Castro-Díez P, Villar-Salvador P, Montserrat-Martí G, Puyravaud JP, Maestro M, Werger MJA, Aerts R (2003) Functional traits of woody plants: correspondence of species rankings between field adults and laboratory grown seedlings? J Veg Sci 14:311-322

Craven D, Dentb D, Bradena D, Ashton MS, Berlyn GP, Hall JS (2011) Seasonal variability of photosynthetic characteristics influences growth of eight tropical tree species at two sites with contrasting precipitation in Panama. For Ecol Manage 261:1643-1653

Delagrange S (2011) Light- and seasonal-induced plasticity in leaf morphology, N partitioning and photosynthetic capacity of two temperate deciduous species. Environ Exp Bot 70:1-10

Diaz S, Hodgson JG, Thompson K, Cabido M, Cornelissen JH, Jalili A, MontserratMarti G, Grime JP, Zarrinkamar F, Asri Y, Band SR (2004) The plant traits that drive ecosystems: evidence from three continents. J Veg Sci 15:295-304

Engelbrecht BMJ, Herz HM (2001) Evaluation of different methods to estimate understorey light conditions in tropical forests. J Trop Ecol 17:207-224

Evans JR, Poorter H (2001) Photosynthetic acclimation of plants to growth irradiance: the relative importance of specific leaf area and nitrogen partitioning in maximizing carbon gain. Plant Cell Environ 24:755-767

Frak E, Le Roux X, Millard P (2001) Changes in total leaf nitrogen and partitioning of leaf nitrogen drive photosynthetic acclimation to light in fully developed walnut leaves. Plant Cell Environ 24:1279-1288 
Garnier E, Shipley B, Roumet C, Laurent G (2001) A standardized protocol for the determination of specific leaf area and leaf dry matter content. Funct Ecol 15:688-695

Gerhardt K (1996) Effects of root competition and canopy openness on survival and growth of tree seedlings in a tropical seasonal dry forest. For Ecol Manage 82:33-48

Gerhardt K, Hytteborn H (1992) Natural dynamics and regeneration methods in tropical dry forests - an introduction. J Veg Sci 3:361-364

Hennenberg KJ, Goetze D, Szarzynski J, Orthmann B, Reineking B, Steinke I, Porembski S (2008) Detection of seasonal variability in microclimatic borders and ecotones between forest and savanna. Basic Appl Ecol 9:275-285

Hikosaka K (2004) Interspecific difference in the photosynthesis-nitrogen relationship: patterns, physiological causes, and ecological importance. J Plant Res 117:481-494

Huante P, Rincón E (1998) Responses to light changes in tropical deciduous woody seedlings with contrasting growth rates. Oecologia 113:53-66

Huante P, Rincon E, Acosta I (1995) Nutrient availability and growth rate of 34 woody 605 species from a tropical deciduous forest in Mexico. Funct Ecol 9:849-858

Kamiyama C, Oikawa S, Kubo T, Hikosaka K (2010) Light interception in species with different functional groups coexisting in moorland plant communities. Oecologia 164:591-599

Kattge J, Knorr W, Raddatz T, Wirth C (2009) Quantifying photosynthetic capacity and its relationship to leaf nitrogen content for global-scale terrestrial biosphere models. Global Change Biol 15:976-991

Khurana E, Singh JS (2001a) Ecology of tree seed and seedlings: implications for tropical forest conservation and restoration. Curr Sci 80:748-757

Khurana E, Singh JS (2001b) Ecology of seed and seedling growth for conservation and restoration of tropical dry forest: a review. Environ Conser 28:39-52

Khurana E, Singh JS (2006) Impact of life-history traits on response of seedlings of five tree species of tropical dry forest to shade. J Trop Ecol 22:653-661

Kitajima K (1994) Relative importance of photosynthetic traits and allocation patterns as correlates of seedling shade tolerance of 13 tropical trees. Oecologia 98:419-428

Kitao M, Lei TT, Koike T, Tobita H, Maruyama Y (2000) Susceptibility to photoinhibition of three deciduous broadleaf tree species with different successional traits raised under various light regimes. Plant Cell Environ 23:81-89

Krishan G, Srivastav SK, Kumar S, Saha SK, Dadhwal VK (2009) Quantifying the underestimation of soil organic carbon by the Walkley and Black technique examples from Himalayan and Central Indian soils. Curr Sci 96:1133-1136

Kröber W, Böhnke M, Welk E, Wirth C, Bruelheide H (2012) Leaf trait-environment relationships in a subtropical broadleaved forest in South-East China. PLoS ONE 7(4):e35742

Krzic M, Fortin M-C, Bomke AA (2000) Short-term responses of soil physical properties to corn tillage-planting systems in a humid maritime climate. Soil Tillage Res 54:171-178

Lambers H, Chapin FS, Pons TL (2008) Plant physiological ecology, 2nd ed. New York, Springer

Landhäusser SM, Lieffers VJ (2001) Photosynthesis and carbon allocation of six boreal tree species grown in understory and open conditions. Tree Physiol $21: 243-250$

Lebrija-Trejos E, Pérez-García EA, Meave JA, Poorter L, Bongers F (2011) Environmental changes during secondary succession in a tropical dry forest in Mexico. J Trop Ecol 27:477-489

Lichtenthaler HK (1998) The stress concept in plants: an introduction. Ann New York Acad Sci 851:187-198

Lieberman D, Li M (1992) Seedling recruitment patterns in a tropical dry forest in Ghana. J Veg Sci 3:375-382

Lusk CH, Reich PB, Montgomery RA, Ackerly DD, Cavender-Bares J (2008) Why are evergreen leaves so contrary about shade? Trends Ecol Evol 23:299-303

Lusk CH, Warton DI (2007) Global meta-analysis shows that relationships of leaf mass per area with species shade tolerance depend on leaf habit and ontogeny. New Phytol 176:764-777

Lüttge U, Kluge M, Bauer G (2002) Botanik. Weinheim, Wiley-VCH-Verlag

Markesteijn L, Poorter L, Bongers F (2007) Light-dependent leaf trait variation in 43 tropical dry forest tree species. Am J Bot 94:515-525

Marod D, Kutintara U, Tanaka H, Nakashizuka T (2004) Effects of drought and fire on seedling survival and growth under contrasting light conditions in a seasonal tropical forest. J Veg Sci 15:691-700

McLaren KP, McDonald MA (2003) The effects of moisture and shade on seed germination and seedling survival in a tropical dry forest in Jamaica. For Ecol Manage 183:61-75
Mulkey SS, Wright SJ (1996) Influence of seasonal drought on the carbon balance of tropical forest plants. In: Mulkey SS, Chazdon RL, Smith AP (eds) Tropical forest plant ecophysiology. Chapman \& Hall, New York, pp 187-216

Niinemets Ü, Kull O, Tenhunen JD (1998) An analysis of light effects on foliar morphology, physiology and light interception in temperate deciduous woody species of contrasting shade tolerance. Tree Physiol 18:681-696

Olsen SR, Sommers LE (1982) Phosphorus. In: Miller RH, Keeney DR (eds) Methods of soil analysis: Part 2. Chemical and Microbiological Properties. Agronomy Mongraph No. 9, 2nd ed. American Society of Agronomy and Soil Science Society of America, Madison, Wl, pp 403-430

Osunkoya OO, Ash JE, Hopkins MS, Graham AW (1994) Influence of seed size and seedling ecological attributes on shade-tolerance of rain-forest tree species in northern Queensland. J Ecol 82:149-163

Poorter H, Bergkotte M (1992) Chemical composition of 24 wild species differing in relative growth rate. Plant Cell Environ 15:221-229

Poorter H, Garnier E (2007) Ecological significance of inherent variation in relative growth rate and its components. In: Functional Plant Ecology, 2nd edn. CRC Press, Boca Raton, FL, USA, pp 67-100

Poorter H, Niinemets Ü, Poorter L, Wright IJ, Villar R (2009) Causes and consequences of variation in leaf mass per area (LMA): a meta-analysis. New Phytol 182:565-588

Poorter $L$, Markesteijn $L$ (2008) Seedling traits determine drought tolerance of tropical tree species. Biotropica 40:321-331

Popma J, Bongers F (1988) The effect of canopy gaps on growth and morphology of seedlings of rain-forest species. Oecologia 75:625-632

Portsmuth A, Poorter H (2007) Structural and physiological plasticity in response to light and nutrients in five temperate deciduous woody species of contrasting shade tolerance. Funct Ecol 21:61-77

Reich PB, Uhl C, Walters MB, Ellsworth DS (1991) Leaf life-span as a determinant of leaf structure and function among 23 Amazonian tree species. Oecologia 86:16-24

Reich PB, Walters MB, Ellsworth DS (1997) From tropics to tundra: global convergence in plant functioning. Proc Nat Acad Sci USA 94:13730-13734

Rincon E, Huante P (1993) Growth responses of tropical deciduous tree seedlings to contrasting light conditions. Trees 7:202-207

Rozendaal DMA, Hurtado VH, Poorter L (2006) Plasticity in leaf traits of 38 tropical tree species in response to light; relationships with light demand and adult stature. Funct Ecol 20:207-216

Sheldrick BH, Wang C (1993) Particle size distribution. In: Soil Sampling and Methods of Analysis. Carter MR (ed.). Canadian Society of Soil Science, Lewis Publishers, pp 499

Shipley B, Vu T-T (2002) Dry matter content as a measure of dry matter concentration in plants and their parts. New Phytol 153:359-364

Singh JS, Singh VK (1992) Phenology of seasonally dry tropical forest. Curr Sci 63: 684-689

Singh R, Sagar R, Srivastava P, Singh P, Singh JS (2017) Herbaceous species diversity and soil attributes along a forest-savanna-grassland continuum in a dry tropical region. Ecol Eng 103:226-235

Sterck FJ, Poorter L, Schieving F (2006) Leaf traits determine the growth-survival trade-off across rain forest tree species. Am Nat 167:758-765

Terashima I, Hanba YT, Tazoe Y, Vyas P, Yano S (2006) Irradiance and phenotype: comparative eco-development of sun and shade leaves in relation to photosynthetic $\mathrm{CO}_{2}$ diffusion. J Exp Bot 57:343-354

Tripathi SN, Raghubanshi AS (2014) Seedling growth of five tropical dry forest tree species in relation to light and nitrogen gradients. J Plant Ecol 7:250-263

Troup RS (1921) The Silviculture of Indian Trees, I-III, p. 783. Clarendon Press, Oxford

Valladares F, Gianoli E, Gómez JM (2007) Ecological limits to plant phenotypic plasticity. New Phytol 176:749-763

Valladares F, Niinemets Ü (2008) Shade tolerance a key plant feature of complex nature and consequences. Ann Rev Ecol Evol Syst 39:237-257

Valladares F, Sánchez-Gómez D, Zavala MA (2006) Quantitative estimation of phenotypic plasticity: bridging the gap between the evolutionary concept and its ecological applications. J Ecol 94:1103-1116

Valladares F, Wright SJ, Lasso E, Kitajima K, Pearcy RW (2000) Plastic phenotypic response to light of 16 congeneric shrubs from a Panamanian rainforest. Ecology 81:1925-1936

Verma DM, Balakrishnan NP, Dixit RD (1993) Flora of Madhya Pradesh, vol I. Botanical Survey of India, Calcutta

Walkley A, Black IA (1934) An examination of the Degtjareff method for determining soil organic matter and a proposed modification of the chromic acid titration method. Soil Sci 37:29-38 
Walters MB, Reich PB (1996) Are shade tolerance, survival, and growth linked? Low light and nitrogen effects on hardwood seedlings. Ecology 77:841-853 Walters MB, Reich PB (1999) Low-light carbon balance and shade tolerance in the seedlings of woody plants: do winter deciduous and broad-leaved evergreen species differ? New Phytol 143:143-154

Warren RJ (2008) Mechanisms driving understorey evergreen herb distributions across slope aspects: as derived from landscape position. Plant Ecol 198: 297-308

Weiher E, van der Werf A, Thompson K, Roderick M, Garnier E, Eriksson O (1999) Challenging Theophrastus: a common core list of plant traits for functional ecology. J Veg Sci 10:609-620

Wright IJ, Reich PB, Westoby M, Ackerly DD, Baruch Z, Bongers F, Cavender-Bares J, Chapin FS, Cornelissen JHC, Diemer M, Flexas J, Garnier E, Groom PK, Gulias J, Hikosaka K, Lamont BB, Lee T, Lee W, Lusk C, Midgley JJ, Navas ML, Niinemets Ü, Oleksyn J, Osada N, Poorter H, Poot P, Prior L, Pyankov VI, Roumet C, Thomas SC, Tjoelker MG, Veneklaas EJ, Villar R (2004) The worldwide leaf economic spectrum. Nature 428:821-827

Wright IJ, Westoby M (2002) Leaves at low versus high rainfall: coordination of structure, lifespan and physiology. New Phytol 155:403-416

\section{Publisher's Note}

Springer Nature remains neutral with regard to jurisdictional claims in published maps and institutional affiliations.

\section{Submit your manuscript to a SpringerOpen ${ }^{\circ}$ journal and benefit from:}

- Convenient online submission

- Rigorous peer review

- Open access: articles freely available online

- High visibility within the field

- Retaining the copyright to your article

Submit your next manuscript at $\boldsymbol{\nabla}$ springeropen.com 